\title{
Effects of calorie and protein deficiencies early in life on the subsequent learning ability of rats
}

\author{
By ANGELA BAIRD, ELSIE M. WIDDOWSON AND J. J. COWLEY \\ Dunn Nutritional Laboratory, Infant Nutrition Research Division, \\ University of Cambridge and Medical Research Council
}

(Received 23 fuly 1970-Accepted 26 October 1970)

\begin{abstract}
I. The effect of malnutrition early in life on the subsequent learning ability of male rats was studied when they were malnourished and after they had been rehabilitated. The HebbWilliams Test of animal intelligence was used.

2. Animals were malnourished from weaning, from birth, or from conception.

3. The rats used for tests were fed on a (I) low-protein, (2) low-calorie, or (3) stock diet.

4. The mean number of errors made by all groups of malnourished animals, tested when they were 13 weeks old, was always greater than that made by the corresponding controls. The same was true after rehabilitation for 5 weeks.
\end{abstract}

The earlier in life an animal is malnourished the greater the effect on its subsequent physical growth and development (Widdowson \& McCance, r963; Winick \& Noble, I966), and the same may apply to its learning ability (Barnes, Cunnold, Zimmermann, Simmons, MacLeod \& Krook, I966; Cowley \& Griesel, I966). The investigation of the last problem is beset with pitfalls, however, for it is difficult to be sure that it is only malnutrition that is affecting behaviour and not something else. For example, in mammals with a period of dependence on the mother, malnutrition of the mother before or during pregnancy and lactation, which undoubtedly has an effect on the growth of her young, may lead to a change in her behaviour towards them, and this in turn may affect their own behaviour. Even when the mother is well-nourished, her maternal behaviour may be affected by the number in the litter she is feeding. Seitz (1954), for example, reported that there is an inverse relationship between the size of a rat litter and the amount of attention each young rat receives, and this has been suggested as one reason why rats reared in large litters grow more slowly than those suckled in small ones (Kennedy, I957-8; Widdowson \& McCance, I960), and why they are less inquisitive and less inclined to explore new surroundings (Lát, Widdowson \& McCance, r960).

If the period of malnutrition begins after weaning, so that the maternal influence is eliminated, the situation is less complicated, and the effect on behaviour may depend on the kind of malnutrition that is imposed. A deficiency of calories for a limited period has often been shown to delay physical growth and development, but there is little evidence whether the deficiency impairs learning ability either when the animal is still undernourished or after it has been rehabilitated. On the other hand, it has been reported that feeding rats on a diet with a low concentration of protein or of a specific amino acid for a limited period permanently affects their performance in mazes (Pilgrim, Zabarenko \& Patton, 195I; Bevan \& Freeman, I952). In the early 
studies, variations in the composition of the diets, the methods of testing and in the age at which the deficient diets were introduced may account for the lack of consistency in the results.

More recently, Barnes et al. (I966) used a Y water maze in a position-reversal test and as a means of evaluating the learning of visual discrimination. The performance in the position-reversal test was poorest in young rats that had been suckled in large litters and then fed on a low (4\%)-protein diet for 8 weeks. Rats suckled in large or medium-sized litters, and then fed on the normal diet, made fewer errors. A visual discrimination test was applied after the rats had been rehabilitated for about 3 months. Again, the rats fed on a diet containing the higher percentage of protein from weaning were better at learning the task than animals that had been suckled in large litters and subsequently fed on the low-protein diet. Barnes et al. considered that the deprivation both before and after weaning was important in affecting learning performance; though it was the deprivation over the whole period that had most influence on behaviour. The control animals appeared to react more strongly to being put in the water maze than the rats which had been deprived in early life, as shown by their swimming frantically back and forth. Cowley \& Griesel (1962, 1964) found that male rats born of mothers that had been fed on a low-protein diet, and themselves reared on the diet, performed less well in an intelligence test involving escape from water and were more timid in an 'open field' than rats born of well-nourished mothers and reared on a normal diet.

In the present study the Rabinovitch \& Rosvold (I95I) modification of the HebbWilliams (Hebb \& Williams, 1946) test of animal 'intelligence' was used to assess the effects of a deficiency of calories and of a deficiency of protein on the performance of male rats both while they were malnourished and also after they had been rehabilitated. There were three experimental classes of rats: (I) malnourished from 4 weeks of age; (2) suckled in large groups and then fed on the deficient diets so that they were malnourished from birth; and (3) born of calorie-deficient or protein-deficient mothers, suckled by deficient mothers and then reared on the deficient diets. The last may be regarded as having been malnourished from conception. Slow growth during the suckling period, whether brought about by a large number of young to one mother, or by feeding the mother on a deficient diet, is believed to be due to an insufficient amount of milk being available and not to any alteration in its composition. The malnutrition up to 3 weeks of age of classes (2) and (3) was therefore due to a deficiency of calories, and it was only after weaning that there was a specific deficiency of protein in any of the experiments.

\section{EXPERIMENTAL}

\section{Plan of the experiments}

Expt $\mathrm{x}$. Rats malnourished after weaning. Laboratory rats of the black and white hooded Lister strain were mated. Litters were reduced to eight at birth. Only males were used, but females were allowed to suck to make up litter size. The young were weaned at 2I d and allowed to eat the stock diet (diet 4I B: Bruce, 1958) for I week. At $28 \mathrm{~d}$ the males from each litter were divided into three treatment groups, control 
(C), low-calorie (LC) and low-protein (LP) so that the average weight of animals in each group was as similar as possible.

The nineteen animals in the control group were housed five or six to a large cage $(33.75 \mathrm{~cm} \times 22.5 \mathrm{~cm} \times 25 \mathrm{~cm})$ in an environmental temperature of $20^{\circ}$ and were fed on unlimited amounts of stock diet. The twenty-three LC animals were housed three to a smaller cage $(35 \mathrm{~cm} \times 16 \cdot 25 \mathrm{~cm} \times \mathrm{II} \cdot 25 \mathrm{~cm})$ at the same temperature as the control group and were given $4 \mathrm{~g}$ stock diet per rat per $\mathrm{d}$ for the first 2 weeks and then $5 \mathrm{~g}$ per rat per $\mathrm{d}$ for the following 7 weeks. The twenty-eight LP animals were housed as the LC group and had unlimited amounts of a diet containing $6 \%$ protein. This was prepared by 'diluting' the stock diet with sugar.

Half the rats in each group were tested in the maze between I I and I 4 weeks of age. At $\mathrm{r}_{4}$ weeks all rats were given unlimited amounts of the stock diet until the end of the experiment. All were tested again at 18 weeks of age.

All the rats in this and subsequent experiments were weighed weekly. Handling of them, which is known to affect their behaviour (Cowley \& Widdowson, r965), was the same in the groups of animals tested together and compared.

Expt 2. Rats malnourished from birth. Normal stock rats were mated as in Expt $\mathrm{I}$. At birth the males and females from all litters, born within any one period of $24 \mathrm{~h}$, were pooled. Sets of eight and seventeen animals were picked out, males being taken preferentially and the numbers made up with females. Each set of eight or seventeen was given to one of the mothers, and any remaining mothers were discarded. All the rats were weaned at $2 \mathrm{I} \mathrm{d}$ and given stock diet until $28 \mathrm{~d}$; then the males of those that had been suckled in sets of seventeen were divided into three groups; one, of ten rats, was offered unlimited amounts of stock diet, and thus represented animals undernourished during the suckling period and well-nourished from weaning; another, of fourteen rats, was given $4 \mathrm{~g}$ then $5 \mathrm{~g}$ stock diet per rat per $\mathrm{d}$ as in $\operatorname{Expt} \mathrm{I}$ (LC); and the other, of fifteen rats, a $6 \%$ protein diet in unlimited amounts (LP). The ten males that had been suckled in sets of eight represented normal well-fed controls and were given unlimited amounts of stock diet from weaning. The animals were trained and tested in the maze, then rehabilitated and tested again as in Expt I.

Expt 3. Rats malnourished from conception. The mothers of the rats in this experiment were eighteen females born of well-nourished mothers and were litter-mates of the control males used for Expt I. They were divided into three groups at weaning; one was given $12 \mathrm{~g}$ stock diet per rat daily (LC), increased to $20-25 \mathrm{~g}$ daily during pregnancy and lactation. A second group received unlimited amounts of a $9 \%$ protein diet (LP). It was necessary to give these females diets that were less deficient than those given to the experimental males of Expts I and 2, to enable them to produce and rear litters successfully. The third group was reared on the stock diet ad lib.

The females were mated with stock males when they reached a body-weight of I $20 \mathrm{~g}$. Their male offspring constituted the experimental animals. These were suckled by their own mothers and treated from birth in the same way as the animals of Expt I. After weaning, five LP and six LC rats died. They were very small, only about $20 \mathrm{~g}$, and evidently they could not maintain their body temperature in small groups of three when the warmth of the mother's body and that of the rest of the litter 
was removed. All remaining rats in the two deficient groups were therefore kept at an environmental temperature of $27^{\circ}$ for the first 2 weeks after weaning. There were nine surviving LC males and sixteen LP animals. Eight males born of well-nourished mothers were used as controls.

\section{Diets}

The pelleted stock diet (4I B) contained $18 \%$ protein. The low-protein diets were made up with powdered diet $4 \mathrm{I} B$, mixed with sucrose, maize oil and mineral and vitamin mixtures in the following proportions:

$6 \%$ protein diet $9 \%$ protein diet

(parts/hundred) (parts/hundred)

$\begin{array}{lcc}\text { Diet 4I B } & 39 & 55 \\ \text { Sucrose } & 52 \cdot 4 & 42 \cdot 4 \\ \text { Maize oil } & 4 \cdot 8 * & 0 \\ \text { Minerals } \dagger & 2 \cdot 5 & \mathrm{I} \cdot 7 \\ \text { Vitamins } & \mathrm{I} \cdot 3 & 0 \cdot 9\end{array}$

* The $6 \%$ protein diet contained maize oil as the rats took the mixture containing this better than a dry powder.

$\uparrow$ Mineral and vitamin mixtures made up according to McCracken (I 969 ).

\section{Modified Hebb-Williams test}

The apparatus. This was a closed-field type devised by Hebb \& Williams (I946) and later modified by Rabinovitch \& Rosvold (195I). A diagram of the apparatus is shown in Fig. I. It was made of galvanized iron sheeting, and it had an expanded aluminium mesh lid, constructed so that the experimenter could see in easily but the rat could not see out; the animal was therefore not distracted by movements outside. The floor was divided by painted lines into $12.5 \mathrm{~cm}$ squares.

The problems were set up by means of moveable galvanized iron barriers which were attached to the floor with small magnets. To enable the rat to distinguish between walls and barriers the latter were painted black, and the walls and goal and starting boxes were metallic grey. 'The two doors were made of thin light metal so that the rats could push them easily; they opened one way only - out of the starting box and into the goal box. Both doors were fitted with a time switch; when the first door was lifted above a certain height a clock was turned on and the time was recorded until the second door was opened; this turned off the clock. The height at which the opening of the door turned on the switch could be adjusted for the size of the rat.

The testing was carried out in a small room, with blacked-out windows, in which the only source of illumination was a shaded light in one corner of the room. External noise was masked by running a small fan continuously throughout the testing. The experimenter stood in the same position for each test, as the rat may use this position as a clue to solving the problem. The temperature of the room remained fairly constant at about $20^{\circ}$.

Training procedure. Preliminary training was given, (I) to accustom the rats to the apparatus, (2) to teach them to go straight to the food box, and (3) to eat as much as possible of their total food requirements for $12 \mathrm{~h}$ during a period of about $15 \mathrm{~min}$. For the $24 \mathrm{~h}$ before the start of the training, the control and LP rats were deprived of 
food. During training both stock diet and $6 \%$ protein diet were available in the goal box: however, all rats chose the stock diet and therefore this alone was put in the goal box during the test runs.

The rats were initially introduced to the apparatus four at a time. Both doors were removed for the first trial and the rats allowed to run freely back and forth from the start to the goal box for a period of about to min. During the next session the door of the starting box only was put into position. On the third, and all successive trials,

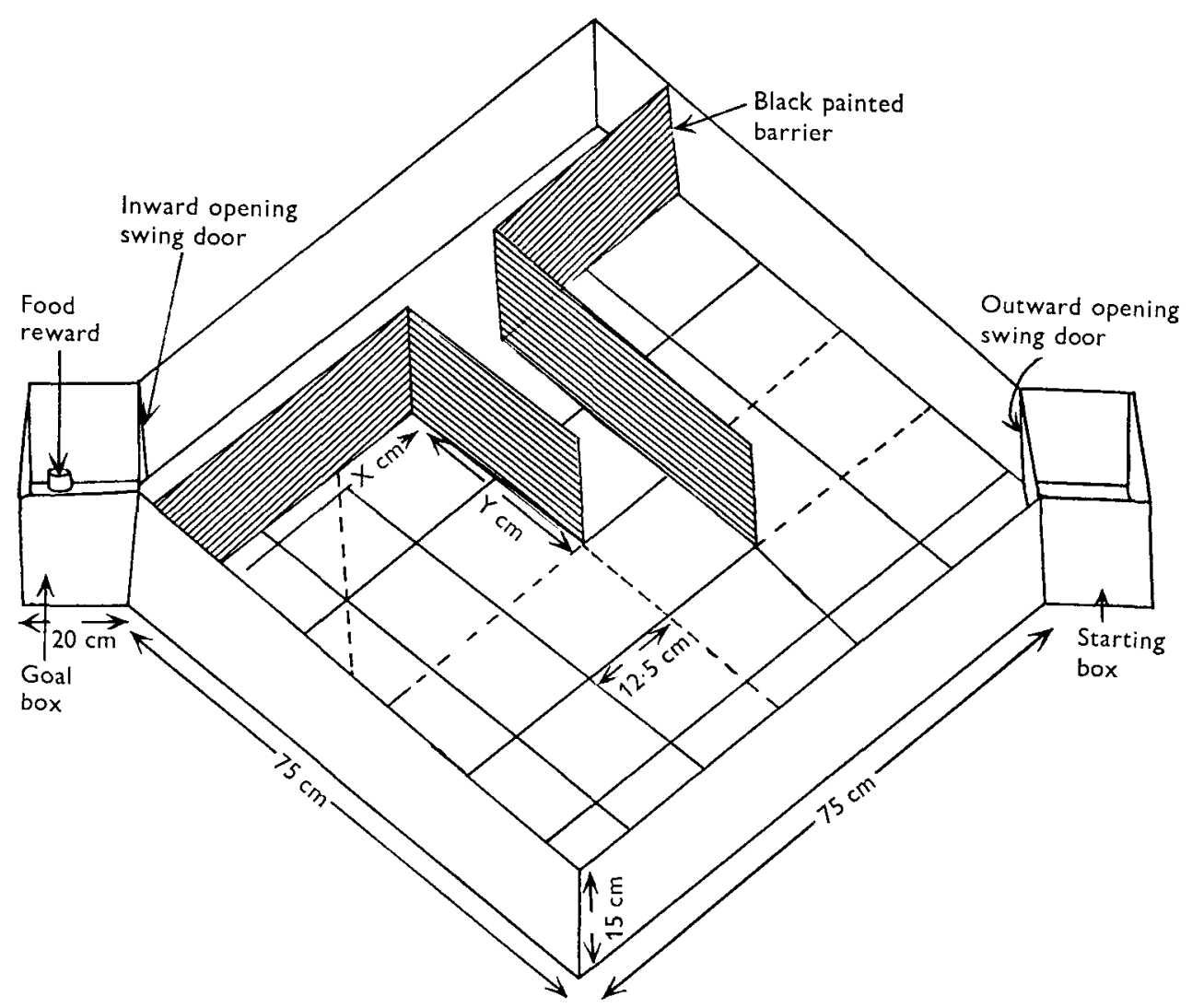

Fig. I. Hebb-Williams apparatus for testing animal intelligence set up for problem $7 . x$ and $y$ are variable lengths of barriers. - - - - - , boundary of error zone.

both doors were in position, although sometimes, when a rat was slower at learning than the rest, the door was propped open with a block. As soon as the animals appeared to be well adapted and capable of opening the doors each rat was run individually, following the suggestions of Rabinovitch \& Rosvold (195I). In each experiment ro $\mathrm{d}$ were allowed for training during the first tests, and all rats that had not reached the required criterion of adaptation by that time were discarded; $5 \mathrm{~d}$ were found to be sufficient for training on the second occasion.

Testing procedure. The testing was carried out over a period of $6 \mathrm{~d}$. Twelve problems were presented, two each day with an interval of 10-14 h between. Every rat was put 
through each problem eight times consecutively and the pathway was traced on a duplicated plan of the maze. On reaching the goal box, each rat was allowed to eat for a few seconds before being put back in the starting box. If on any one of the eight runs a rat failed to reach the goal box in 2 min it was taken out of the maze and that run was discounted. It was then made to run once more, and if it again failed its score for that problem was disregarded. After each problem the rats were allowed to feed for $I_{5} \mathrm{~min}$, as in the training sessions.

The apparatus was wiped clean after each rat but not between each run of any one rat. The problem used, and the method of scoring errors, were those described by Rabinovitch \& Rosvold (195I); errors were scored whenever the rat deviated from the most direct route from the starting box to the goal.

\section{Number of rats at different stages of the experiments}

Table I shows the numbers of rats in each group at the start of the three experiments, of those that died or failed to be trained, and of those that were successfully trained and tested. In Expt $\mathrm{x}$ half the rats were tested twice, the others only after they

Table г. Numbers of rats at different stages of the experiments

\begin{tabular}{|c|c|c|c|c|c|c|c|c|c|}
\hline $\begin{array}{c}\text { Expt } \\
\text { no. }\end{array}$ & $\begin{array}{l}\text { Treat- } \\
\text { ment } \\
\text { group }\end{array}$ & $\begin{array}{l}\text { No, at } \\
\text { start } \\
\text { of expt }\end{array}$ & $\begin{array}{c}\text { Deaths } \\
\text { during } \\
7 \text { weeks } \\
\text { of } \\
\text { malnu- } \\
\text { trition }\end{array}$ & $\begin{array}{l}\text { No. at } \\
\text { start of } \\
\text { training }\end{array}$ & $\begin{array}{l}\text { Deaths } \\
\text { during } \\
\text { training }\end{array}$ & $\begin{array}{c}\text { Failures } \\
\text { to } \\
\text { train }\end{array}$ & $\begin{array}{l}\text { No. } \\
\text { tested at } \\
\text { end of } \\
\text { malnu- } \\
\text { trition }\end{array}$ & $\begin{array}{l}\text { Deaths } \\
\text { during } \\
\text { rehabili- } \\
\text { tation }\end{array}$ & $\begin{array}{l}\text { No. tested } \\
\text { after } \\
\text { rehabili- } \\
\text { tation }\end{array}$ \\
\hline \multirow[t]{6}{*}{ I } & C & 9 & 0 & 9 & 0 & 0 & 9 & I & 8 \\
\hline & $\mathrm{C}$ & I0 & 0 & 10 & 0 & I & 0 & 0 & 9 \\
\hline & LP & 14 & 3 & I I & 2 & 0 & 9 & 0 & $6^{*}$ \\
\hline & LP & 14 & I & 13 & I & 2 & 0 & 0 & IO \\
\hline & LC & 10 & I & 9 & 0 & 0 & 9 & 0 & 9 \\
\hline & LC & I 3 & 2 & I I & 0 & I & 0 & 0 & 10 \\
\hline \multirow[t]{4}{*}{2} & C & 10 & 0 & IO & I & 0 & 9 & 0 & 9 \\
\hline & EC & 10 & 0 & ro & 0 & 0 & Io & I & 9 \\
\hline & LP & I 5 & 0 & I5 & 3 & I & I I & 0 & I I \\
\hline & LC & I4 & 0 & 14 & 7 & I & 6 & 0 & 6 \\
\hline \multirow[t]{3}{*}{3} & C & 8 & 0 & 8 & 0 & I & 7 & 0 & 7 \\
\hline & LP & $2 I$ & 5 & I6 & 2 & 0 & I4 & I & 13 \\
\hline & LC & I5 & 6 & 9 & I & 0 & 8 & 0 & 8 \\
\hline
\end{tabular}

C, control; EC, 'experimental' control; LP, low-protein; LC, low-calorie.

* Three rats were omitted from the second testing as their cage was dropped and it was thought that this might affect their behaviour.

had been rehabilitated. In Expts 2 and 3 all animals were tested twice. The number of rats tested was admittedly small, but the Hebb-Williams test is very time-consuming, and about $6 \mathrm{~h}$ are devoted to the training and testing of each rat. This limited the number of animals in the experiments, though the size of the groups was not different from those used by Barnes et al. (rg66) and the variation in test performance was similar to that reported by others (Cowley \& Griesel, I966). 
RESULTS

Body-weights

Figs. 2-5 show the mean growth curves for all groups of animals in the experiments.

Fig. 2, growth of the animals in Expt 1 , shows that the mean weights of the three groups of animals were almost equal at 4 weeks of age when the experiment started. From this time, when the rats were eating their respective diets, the growth of the malnourished rats in the LC and LP groups was retarded and the weight increased only to $60-70 \mathrm{~g}$ over the next 7 weeks, compared with an increase in the weight of

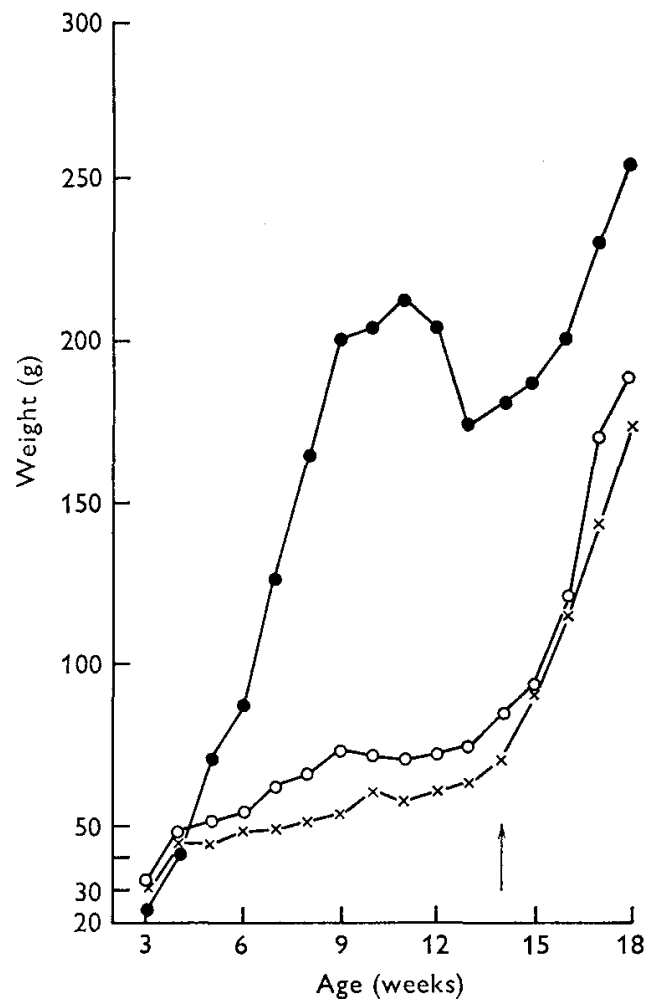

Fig. 2. Weights of rats tested twice in Expt $\mathbf{r}$. - controls; $\bigcirc-\mathrm{O}$, low-calorie group; $x-x$, low-protein group; $\uparrow$, start of rehabilitation.

the animals in the control group to $200 \mathrm{~g}$ over the same period. From II to I4 weeks, during training and testing the body-weight of the controls fell by about $4 \circ \mathrm{g}$. This was due to the fact that these animals were starved for $24 \mathrm{~h}$ immediately before the 2-week training period began, and because they were only allowed food for $15 \mathrm{~min}$ twice each day during training and testing, and they had no food for the remainder of the time. The LC and LP animals were treated in the same way during training and testing, but this pattern of feeding with the stock diet was similar to that to which the LC animals were accustomed, and their weight curve did not show any sudden change. 
The LP animals benefited during this time, for they chose to eat the stock diet, and not the low-protein mixture. These animals gained weight. A drop in weight similar to that of the controls probably occurred in all groups during the second testing after rehabilitation, but weights were not recorded after I 8 weeks. At I4 weeks, when the first testing was finished, all rats were allowed access to unlimited amounts of stock diet: their weights then increased. At the start of the second training, at I 8 weeks, the animals in the two previously malnourished groups were much closer in weight to the controls than they had been at the first testing, although the mean weights were still only $\mathrm{I} 80 \mathrm{~g}$, as compared with a weight of $250 \mathrm{~g}$ for the controls.

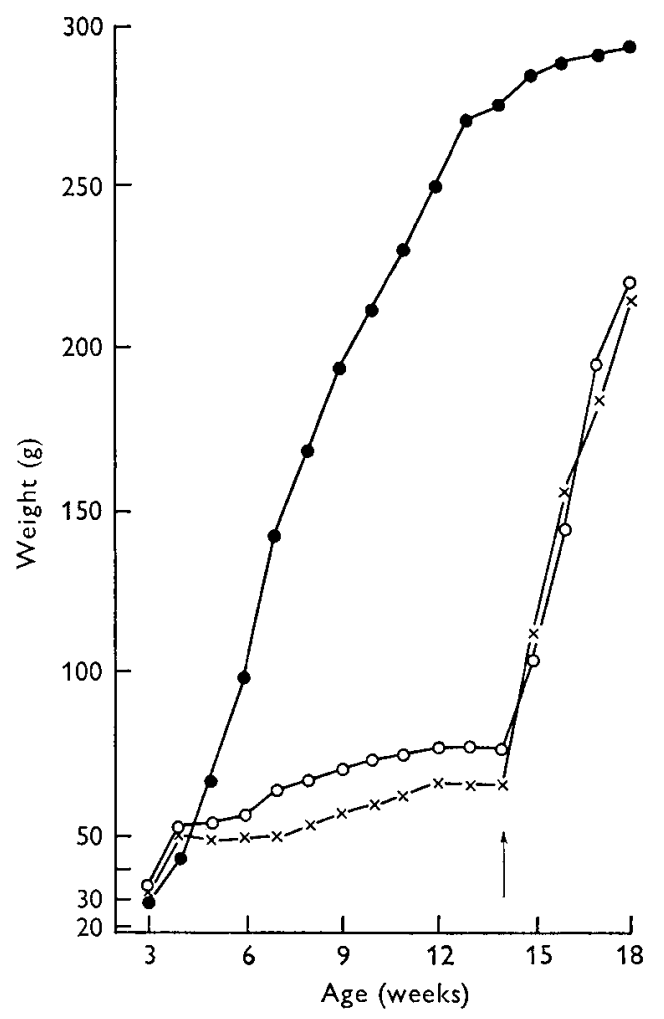

Fig. 3. Weights of rats tested for the first time after rehabilitation in Expt I. - controls; $\mathrm{O}-\mathrm{O}$, low-calorie group; $\times-\times$, low-protein group; $\uparrow$, start of rehabilitation.

Fig. 3 shows the weights of the animals tested for the first time after rehabilitation. The growth of the malnourished rats was similar to that of the animals just described. The animals in the control group also grew similarly, but the drop in weight between I I and I4 weeks did not occur since these animals were not tested until i 8 weeks old and therefore not deprived of food between II and I4 weeks.

Fig. 4 shows the growth of rats malnourished from birth (Expt 2). The controls, suckled in sets of eight and then allowed the stock diet ad lib., weighed the same as those in the other experiments. The rats suckled in sets of seventeen were smaller at 4 weeks than those suckled in sets of eight. From 4 weeks the animals suckled in large 
numbers, and then given unlimited amounts of the stock diet ("experimental' controls) increased in weight in parallel with the control group, but throughout the whole experiment remained about Io-20 g lighter. The LP and LC animals gained about the same weight as those in Expt I, but they were smaller at weaning and they were still about ro g lighter during the test period.

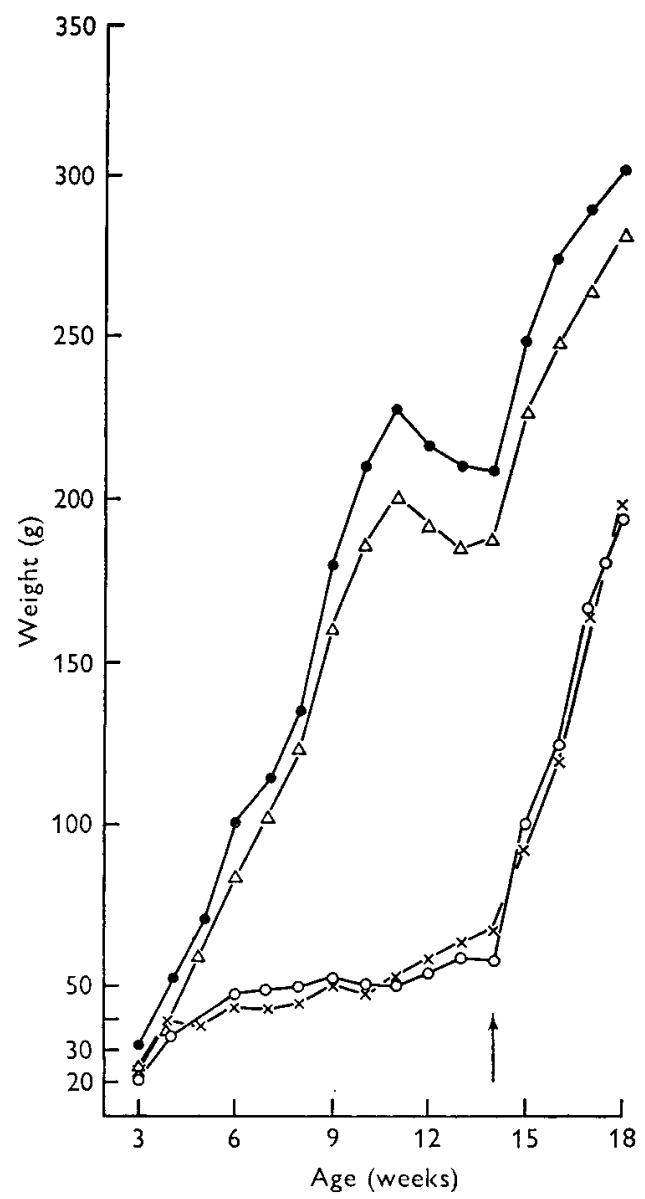

Fig. 4

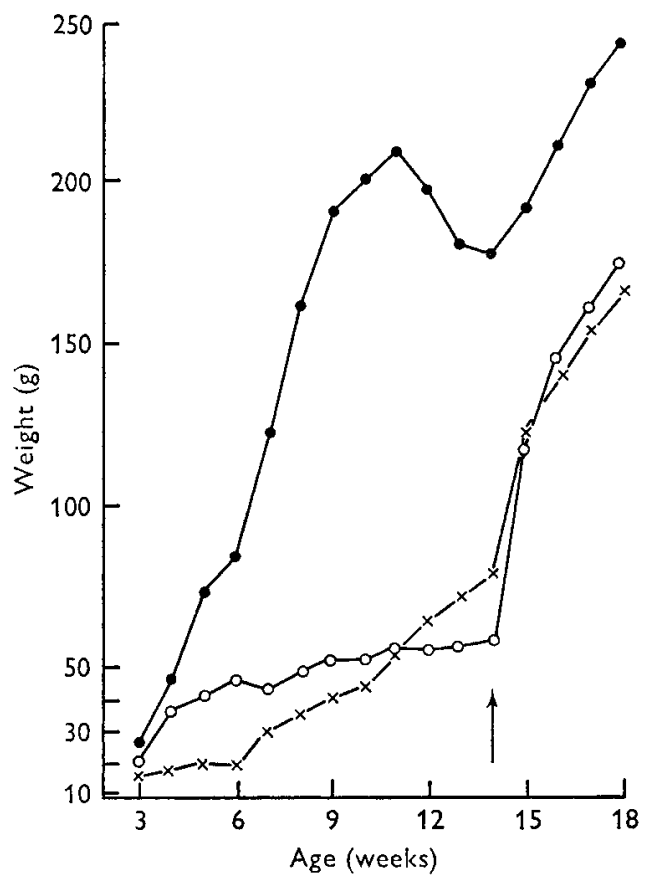

Fig. 5

Fig. 4. Weights of rats in Expt 2. - controls; $\triangle-\Delta$, 'experimental' controls; $0-0$, low-calorie group; $x-x$, low-protein group; $\uparrow$, start of rehabilitation.

Fig. 5. Weights of rats in Expt 3. - controls; $O-O$, low-calorie group; $x-\times$, low-protein group; $\uparrow$, start of rehabilitation.

Fig. 5 shows the weights of the animals malnourished from conception and their well-nourished controls (Expt 3). In this experiment the three groups had different mean weights at 4 weeks when the experimental diets were started: the mean weight of the control group, as of those in Expts I and 2, was about $45 \mathrm{~g}$; the LP animals, whose mothers had lived on a $9 \%$ protein diet since they were weaned, weighed only I $8 \mathrm{~g}$. The LC animals, whose mothers had been given only sufficient of the stock diet 
to keep their weights the same as those of the mothers having the low-protein diet, had grown rapidly from $2 \mathrm{I} g$ to $3^{6} \mathrm{~g}$ between 3 and 4 weeks. By II weeks both malnourished groups had a mean weight of about $54 \mathrm{~g}$, which was about the same as that of the malnourished animals in Expt 2. At 18 weeks the rehabilitated malnourished animals weighed $170 \mathrm{~g}$, compared with $180-2 \mathrm{I} \circ \mathrm{g}$ for the corresponding animals in Expts $I$ and 2.

\section{Performance of the rats during the tests}

Occasionally a rat failed to complete one of the eight runs of a problem within $2 \mathrm{~min}$; when this happened the rat was taken out of the maze and the number of errors was counted as those made in a time of $2 \mathrm{~min}$. When a rat failed to complete two consecutive runs it was not given another opportunity to solve that problem and it was assigned a total score for that problem of one more than the highest score of any rat in its own group. It was only necessary to do this in about $\mathrm{I} \%$ of the total problem scores for all the three experiments.

Table 2. Expt 1. Statistical analysis of errors scored in the Hebb-Williams test by rats born of well-nourished mothers, suckled by them, reared on deficient diets and then rehabilitated

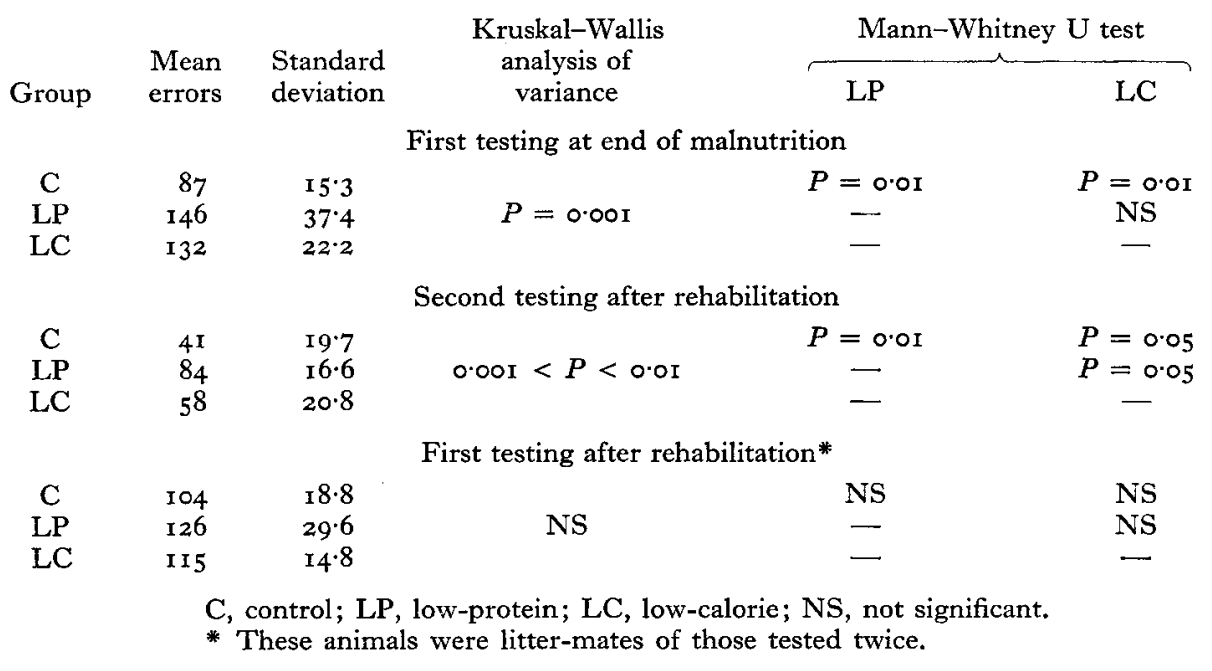

The Kruskal-Wallis analysis of variance was applied to the total number of errors made by each rat in the three groups and, if this showed a high probability of significance, the results were analysed further by the Mann-Whitney one-tailed $U$ test (Siegel, 1956). The results are set out in Tables 2, 3 and 4 with mean error scores, and the standard deviations for each diet group.

Table 2 shows a statistical analysis of the results of Expt I. The LP and LC animals made significantly more errors than the well-nourished controls at the end of the period of malnutrition, but there was no significant difference between the errors made by the two malnourished groups. After these malnourished animals had been rehabili- 
tated for 5 weeks, all three groups made fewer errors than on the first occasion; the controls, however, improved more than the previously malnourished groups; hence there was a significant difference between the controls and each of the previously malnourished groups. There was also a significant difference between the LP and LC groups themselves, the previously protein-deficient rats making more errors. The littermates of these animals tested for the first time after rehabilitation produced results in the same direction, but the differences were not significant.

Table 3. Expt 2. Statistical analysis of errors scored in the Hebb-Williams test by rats born of well-nourished mothers, suckled in large groups, reared on the deficient diets and then rehabilitated

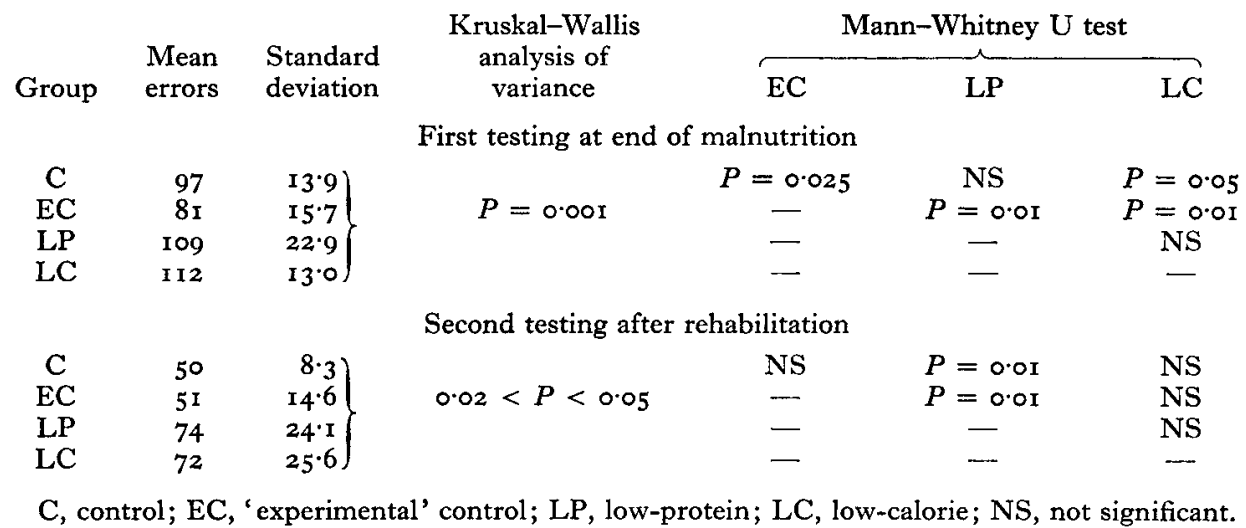

Table 4. Expt 3. Statistical analysis of errors scored in the Hebb-Williams test by rats born of malnourished mothers, suckled by them, reared on the deficient diets and then rehabilitated

\begin{tabular}{|c|c|c|c|c|c|}
\hline \multirow[b]{2}{*}{ Group } & \multirow[b]{2}{*}{$\begin{array}{l}\text { Mean } \\
\text { errors }\end{array}$} & \multirow{2}{*}{$\begin{array}{l}\text { Standard } \\
\text { deviation }\end{array}$} & \multirow{2}{*}{$\begin{array}{c}\text { Kruskal-Wallis } \\
\text { analysis of } \\
\text { variance }\end{array}$} & \multicolumn{2}{|c|}{ Mann-Whitney $U$ test } \\
\hline & & & & LP & LC \\
\hline \multicolumn{6}{|c|}{ First testing at end of malnutrition } \\
\hline C & 98 & $12 \cdot 2$ & & NS & NS \\
\hline LP & 109 & $2 \mathrm{I} \cdot 3$ & NS & - & NS \\
\hline $\mathrm{LC}$ & 104 & $15 \cdot 5$ & & - & 一 \\
\hline \multicolumn{6}{|c|}{ Second testing after rehabilitation } \\
\hline $\mathrm{C}$ & 62 & $10 \cdot 6$ & & NS & NS \\
\hline LP & 67 & $12 \cdot 5$ & NS & 一 & NS \\
\hline LC & 72 & II $\cdot 8$ & & 一 & $\longrightarrow$ \\
\hline
\end{tabular}

Table 3 shows a statistical analysis of the results of Expt 2. At the end of the period of malnutrition there was a significant difference between the groups $(P=$ 0.001 ). On further analysis, the difference was found to be primarily between the 'experimental' controls and the two malnourished groups. After rehabilitation, although the results were in the same direction, the level of significance was not as high. 
Table 4 shows a statistical analysis of the results of Expt 3. Although all the results are in the same direction as in the other experiments no significant differences were found either at the end of the period of malnutrition or after 5 weeks of rehabilitation.

\section{DISCUSSION}

The results of this study suggest that a malnourished animal performs less well than a well-nourished one in the Hebb-Williams test; that a low-protein diet is rather more harmful in this respect than a low-calorie one; and that the effect of the deficient diet persists after 5 weeks rehabilitation.

The use of a food reward in training and during the testing of the rats is not entirely satisfactory, but the Hebb-Williams test was designed to minimize fluctuations in motivation (Hebb \& Williams, 1946) and there is evidence to show that it does so. Short periods of food deprivation have little effect on problem-solving performance (Das \& Broadhurst, 1959). In selecting a food reward, the problem of the animals being differentially affected is not overcome, but the procedure adopted was not likely to facilitate the performance of the control animals more than that of the undernourished. Contrary to the findings of Cowley \& Griesel (1966), the protein-deficient animals, during training, were observed to prefer the stock diet to their own $6 \%$ diet.

We know that the effect of undernutrition on the size and chemical structure of the brain is greater and more likely to be permanent the earlier in development the malnutrition is imposed (Dobbing \& Widdowson, 1965; Winick \& Noble, 1966). Admittedly no-one has yet shown a direct relationship between brain composition and behaviour, but if there is any connexion one might reasonably expect them to be directly rather than inversely related. The results of the present study demonstrate the difficulty of this type of work. The apparently greater effect of malnutrition from weaning than of malnutrition from conception, and the variation in error scores from one batch of control animals to another, make one cautious about drawing any firm conclusions at all.

Nevertheless, for all groups in all experiments the results were invariably in the same direction, and the malnourished animals always made more errors than their controls. Generally, the LP animals had higher error scores than the LC.

Barnett, Smart \& Widdowson (197I) used animals similar to those in Expt I but did not study them until the malnourished animals had been rehabilitated for 22 weeks and their weights were nearly equal to those of the well-nourished controls. Even after this long period of rehabilitation, the previously protein-deficient animals were more active, in a 'residential maze', than the previously calorie-deficient animals or the controls. On the basis of the work of Lát (1965) they suggest that excess of carbohydrate rather than deficiency of protein could have been important in producing this hyperactivity. If so, this would apply with equal force to the results of the present study.

We should like to thank Miss Jean Cowen for looking after the rats, and Mr David Wise for helping with the statistical calculations. 


\section{REFERENCES}

Barnett, S. A., Smart, J. L. \& Widdowson, E. M. (r97r). Devl. Psychobiol. (In the Press).

Barnes, R. H., Cunnold, S. R., Zimmermann, R. R., Simmons, H., MacLeod, R. B. \& Krook, L. (1966). F. Nutr. 89, 399.

Bevan, W. \& Freeman, O. I. (1952). F. genet. Psychol. 80, 75.

Bruce, H. M. (1958). Stud. Fert. 9, 90.

Cowley, J. J. \& Griesel, R. D. (I962). Psychologia Africana 9, 2 I6.

Cowley, J. J. \& Griesel, R. D. (1964). F. genet. Psychol. 104, 89.

Cowley, J. J. \& Griesel, R. D. (1966). Anim. Behav. 14, 506.

Cowley, J. J. \& Widdowson, E. M. (I965). Br. Y. Nutr. I9, 397.

Das, G. \& Broadhurst, P. L. (1959). F. comp. physiol. Psychol. 52, 300.

Dobbing, J. \& Widdowson, E. M. (1965). Brain 88, 357 .

Hebb, D. O. \& Williams, K. (1946). F. gen. Psychol. 34, 59.

Kennedy, G. C. (1957-8). F. Endocr. x6, 9.

Lát, J. (1965). Int. pharmac. Meet. II. Prague, I963, p. 47.

Lát, J., Widdowson, E. M. \& McCance, R. A. (1960). Proc. R. Soc. B 153, 347.

McCracken, K. J. (1969). Energy metabolism of young rats subjected to a deficiency of calories or of protein. PhD Thesis, University of Cambridge.

Pilgrim, F. J., Zabarenko, L. M. \& Patton, R. A. (195I). J. comp. Psychol. 44, 26.

Rabinovitch, M. S. \& Rosvold, H. E. (195I). Can. F. Psychol. 5, 122.

Seitz, P. F. D. (1954). Am. Y. Psychiat. r10, 9r6.

Siegel, S. (1956). Nonparametric Statistics for the Behavioral Sciences. International Student Edition. London: McGraw-Hill Book Company, Inc.

Widdowson, E. M. \& McCance, R. A. (1960). Proc. R. Soc. B I52, I88.

Widdowson, E. M. \& McCance, R. A. (I963). Proc. R. Soc. B 158, 329.

Winick, M. \& Noble, A. (1966). F. Nutr. 89, 300. 